\title{
THE UNWORTHY VICTIM: POLICE DISCRETION IN THE CREDIBILITY CALL
}

\author{
H. RichaRd UVILLER*
}

\section{INTRODUCTION}

Wherever power is lodged, discretion flows. Wide or narrow, considered or unconscious, authoritative choices are made by police up and down the line of command. Recognized, studied, described, and criticized, field discretion exercised by police often guides the decision to charge a person with the commission of a crime. Among the factors in that choice, one large variable remains cloudy: the character and credibility of the victim.

This article examines that factor in the context of some observations I made while in the company of a small group of police officers in New York City's Ninth Precinct during the six months from February to July 1983. I entered this rather unusual sabbatical research project with uncertain objectives, and I emerge with uncertain conclusions. I developed no quantifiable data and I attempted no comparative observations. As a result, I hesitate to term the research empirical. It is certainly not complete. Yet for me, the experience proved valuable, and I have been persuaded to share it for whatever modest illumination it may provide for an otherwise rather obscure area of the criminal process.

Throughout my professional career-fourteen years as a prosecutor in New York County and sixteen years as a teacher-the police officer has been at the center of my thinking. To a young Assistant District Attorney, assessing or preparing a case for trial, the cop is the main source of information and often the star witness as well. But despite a common cause and some teammate camaraderie, I always felt an arm's length between us. For one thing, I was always anxious to assert my role: whatever the authority of the cop in the conduct of the case theretofore, I was the prosecutor and I was in charge. I was also conscious of a professional obligation of objectivity; I knew that I should regard police accounts with skepticism if not suspicion. I was-as the "quasi-judicial" officer I fancied myself-bound to challenge and, if dubious, discard the officer's account of the facts. I am mercifully unaware of how I carried off this proud role, but I am quite sure that my performance did little to encourage my police witnesses to relax and display the flaws and gaps in 
their investigatory work. One role begets another, and generally they were at least as adroit at playing theirs as I was in playing mine.

Since becoming a teacher, I have probably removed the cop still closer to pure construct. To the academic court watcher, the cop often becomes a stick figure in the law enforcement machinery, endowed with a standardized set of motives and responses. Though engaged in the often competitive enterprise of ferreting out crime, police are subject to deterrence by deprivation of illegally acquired evidence. So goes the creature of judicial imagination. To be sure, I had read of the actual exploits of real cops in the opinions of appellate judges, but I rarely paused to wonder how many modifications the tale had undergone as it progressed through the hands of the advocates and the various intermediate tribunals on the way to the final official version of "the facts." Still, I kept that indistinct, sanitized, mythologized, imagined figure of the cop front and center in my mind: I was constantly wondering if he had read the latest in the series of automobile search cases; whether he thought of those cases when he approached a suspicious vehicle on the street; when and with what inflection he informed his captive of his Miranda rights; and what conversation developed between them before and after.

My sabbatical project was designed to refresh my perception of this central figure in the criminal process with some ground level observations of real cops actually working in the law enforcement enterprise. I was aware of the work of the brave few who had studied police conduct in the field. Their sophisticated, and well-funded, research was largely concerned with the quantifiable output of patrol, dealing with minor violations such as traffic infractions, loitering, and the like. These elaborate empirical reports could not provide me with the models I needed for my more modest ambitions. In addition, I was interested in the behavior of the police in handling more serious crimes. I figured that harder choices were being made by the cops in the heavier cases. Higher stakes make cops think twice. Even in the hazy, preliminary planning of this project, I found myself most concerned with the decisional process, the moment's hesitation, the insertion of reconsideration into the ordinary action orientation of the working cop.

So, equipped with a generous carte blanche authorization from the Commissioner's office (for which I am enormously grateful to my friends Bob McGuire and Ken Conboy), I set forth. After several tours as the guest of various teams of uniformed officers in my rather tame home precinct, I decided that I must move to an uglier environment.

The Ninth Precinct, immediately to the east of my own, was regarded as one of the City's dirtiest. The precinct is bounded on the north by 14th Street, on the south by Houston Street, on the west by Broadway, and on the east by the river. For those not familiar with New York, that is roughly a square mile, and includes about half of the district we call the Lower East Side. To many, it is known as the East Village. Several blocks are quite attractive, boasting well-kept brickfront houses and clean sidewalks. Along its eastern edge, the precinct has a large municipal housing development 
providing apartments for lower income families. Some legitimate commerce is carried on in the area. A variety of restaurants, including New York's most notable concentration of Indian and Pakistani places, may be found in the precinct. In addition there are a number of ethnic fast food takeout joints and an assortment of other small local business establishments. But the bourgeois look does not predominate. Blue and pink hairdos decorate the funky St. Mark's place, long the headquarters of punk and its lineal antecedents. Homeless men congregate around a shelter in the precinct. Much of the area is blighted. Abandoned or city-owned buildings gape with empty windows upon streets filthy with refuse. Square blocks have been leveled to rubblestrewn expanses in which a lone building or two might remain, their apertures covered by tin panels or bricked up by cinderblock. The spray paint of the urban ghetto has done its work in the area although, surprisingly, many of the walls and steel shutters have been brightly painted with murals, including one block-long expanse of deserted sandy beach and blue sea.

Shortly before my arrival, the Ninth Precinct formed a unit devoted exclusively to the thorough and vigorous investigation of the crime of robbery. I thought the unit ideally suited to my own investigatory purposes and attached myself to them. The plague of the Ninth Precinct, as one might expect, is drugs. In the darkened hallways of precinct tenements, through holes broken through cinderblocks, from hidden perches in the inaccessible upper reaches of empty houses, heroin and cocaine are dispensed in awesome quantities to an unending parade of customers, many of them "respectable" citizens of our own and neighboring communities and states. Constant law enforcement efforts on both the street and wholesale levels have done little to reduce the flourishing trade. 1 On many corners, posted lookouts stand ready to sound the alarm whenever cops enter the block. Along the curbs, silent men lounge against the parked cars or stare from doorways, waiting to steer the customers to the drugs they seek-or to robbery. To a certain extent, the well-staffed drug operations protect their clientele against the depredations of invading hold-up men. But the drug-hungry shoppers are inviting targets of opportunity. Easily recognizable, often from out of town, usually reluctant to press charges, and (at least on the way into the precinct) carrying cash, they draw the predators like yellowjackets at a picnic. And in an area infested with thieves, armed and experienced, no one is safe.

1. Subsequent to my work in the precinct, the police department instituted an operation dubbed "Pressurepoint," which saturated the area with uniformed officers drawn from other precincts, along with special tactical forces. The cops maintain "aggressive patrol," concentrating in the areas where the drug traffic had been heaviest. In a recent visit, I saw for myself what the cops of the robbery unit had reported. At least for the moment, the scene was transformed: No one seemed to know where the pervasive drug dealers and their loitering adjuncts had gone, but the streets now appear to belong to the residents. 


\section{II \\ “9 RIP"}

The unit I chose to observe-the Robbery Identification Program of the Ninth Precinct, known as "9 RIP" on the air-comprised twelve men under the command of a sergeant. The men had been drawn from the precinct detective squad, the special patrol group known as "anti-crime," and the central robbery command. Some held the rank of detective; others still carried the silver badge of patrol. They represented a surprisingly broad range of seniority, experience, personality, and "life-style." They worked, usually in teams of four, in two shifts: from 8 a.m. to 4 p.m. and from 4 p.m. to $1 \mathrm{a} . \mathrm{m}$. The mission of 9 RIP was to investigate every robbery in the precinct, to make arrests where appropriate, and to "enhance" the cases made by a uniformed officer's arrest on the street. The job called for persistent and imaginative work, with an eye toward courtroom results.

In the big cities, at least, police rarely work to enrich a case from a trial standpoint, even in such major crimes as robbery. While cops arrest criminals who fall into their outstretched arms, and may even pursue the fleeing felon, they rarely develop a case by investigation, from complaint to capture. (Homicides are a notable exception to this general rule. There are other occasional, exceptional cases.) As a result, witnesses may be missed and physical evidence may be ignored. The object of the RIP units was to supply the missing work. The men took the responsibility seriously. I saw the sort of investigative energy expended by this group that should be rewarding to those who conceived the operation. And, insofar as the statistics are meaningful, the numbers tended to confirm the effectiveness of the program.

The aspect of their work discussed here is one that the men themselves found troubling. While they did not articulate it in precisely the way I might, the problem arose and was discussed often enough for me to believe that it was a matter of genuine concern. The question for examination is this: whether the cop should make an arrest on the complaint of an individual who is, in the best judgment of the officer, unworthy of belief.

\section{III}

\section{A CASE}

The question may best be illustrated with a case. One afternoon I was with a group of three cops when they decided to check out a robbery complaint that Muldoon, a patrol officer, had picked up the day before. The three officers were Tom Trepcyk, Rocco Regina, and Joe Byrne. Trepcyk had nineteen years on the job. He had been on a number of assignments, including the highly sensitive internal anticorruption unit. Divorced, he lived in the West Village. Tom lifted weights and looked it, wore tight-fitting jeans, uncut hair and a full beard, and came to work carrying a shoulder bag (usually with his gun in it). He worked as a stuntman in the movies during his off time and often wore a silver satin jacket with the name of a recent film job- "The 
Verdict"-emblazoned across the back. Regina was a tough-talking young cop who knew the back alleys of the precinct from his days on anti-crime patrol. "Rocky" had been promoted recently to the rank of detective. He drove fast when responding to emergency calls, and took no back talk from the people on the street. A sometime auto mechanic, he was also a serious cabinetmaker. Until he chose to reveal his gentler nature, Rocky could easily have been described as the tough guy in the outfit. Byrne was the new man on the RIP roster. Joe had come up only recently from the precinct anti-crime unit and was still getting the feel of the deck in RIP. He seemed particularly bright, thoughtful, sympathetic, and good-humored by nature. ${ }^{2}$

We parked outside the fleabag hotel where the complainant lived and followed the clerk through a maze of narrow hallways to her door. When she emerged in response to Regina's knock, we saw a young and somewhat disheveled Black woman. As Regina questioned her, wedged in that dim space in front of her door, she recited the facts to us.

The previous afternoon, after cashing her welfare check and secreting sixty-odd dollars in her sock (because, she explained, she wore no underwear), she had decided to go to the movies. She went across the street from her hotel where a landmark bowery theater functioned as a porn and horror movie house. Slowly, to make sure we understood, the complainant demonstrated how she had reached down into her sock to get the price of the ticket, all in the full view of both the "old lady" selling tickets from the outdoor booth, the man taking the tickets just inside the glass doors (and anyone else who happened to be passing by on the street at that moment.) She then went inside and up to the balcony where, she told us, she was distracted by the unfamiliar sight of two men engaged in sexual activity in the row in front of her. At that point, according to her account, a flashlight was shined first in her face, then on an open knife, and then on the face of the holder of the knife and the flashlight. In the beam she recognized the face of the man who had taken her ticket a short while before. The man reached into her sock, took her money, and left. She immediately went out to the theater lobby, where she saw the robber back at his post. She ran out into the street where she flagged down a passing radio car and made her complaint to Muldoon.

Having recounted these events, she told us confidentially that she was aware of the fact that some police officers are corrupt, or for other reasons inattentive to duty, and suggested that Muldoon's failure to arrest the ticket taker on the spot was suspicious. She hotly denied that she had been drinking or was under the influence of any drug. She exhibited the insides of her arms as proof that she did not use drugs. I asked her how her attacker had managed to hold a knife in one hand, a flashlight in the other, and still keep one hand free to fish in her sock for the loot. She tried to explain the manuever again. Regina asked some more questions. It was soon apparent, however,

2. Byrne shortly afterward passed the sergeant's exam and was promoted to a supervisory patrol position on the Upper Eastside. 
that our victim was not to be shaken from her original story, vowing that she would go to court and swear to every detail. We told her we would be back.

Downstairs, standing next to our car, we discussed the case. All of us were thinking the same thing: Was this woman giving us a straight story? Regina was not ready to say she was lying, but it was clear that he did not entirely believe her either. He decided to ask her to come down and go over to the movie theater. He wanted to see if she could make a positive identification.

This time Regina went upstairs alone and was gone several minutes, taking the complainant through the story again. In the interim, I decided to put the question flatly to Trepcyk and Byrne: Did they believe the story? Both were of one mind, believing that the woman had undoubtedly lost her money, that perhaps she had even been robbed in the dark of the theater, but that her description of the incident was incredible. They speculated that perhaps she was telling the story to try to get the theater to make good her loss. Despite these thoughts, Trepcyk seemed sure, and Byrne did not demur, that the question of credibility was not a consideration on which police action could be based.

As we approached the window of the outside ticket booth a short time later, our complainant at once pointed an accusatory finger at the stocky, middle-aged Hispanic man in the booth. "That's him," she told us with conviction. Regina began to ask questions. He spoke to the accused man in the booth, to a well-spoken, managerial young man who appeared from inside the theater, and to the theater manager in his small cluttered office upstairs behind the projection room. Their accounts were interlocking and mutually corroborative: on the previous day, the complainant had appeared to be under the influence of alcohol or drugs. She had purchased a ticket from the elderly woman on duty in the booth, and had gone up to the balcony. Some while later, she had returned to the lobby, loudly accused the ticket taker-the same person who was today selling tickets from the booth-of robbing her at knifepoint, and flagged down a passing patrol car to repeat her accusation to the police. The police officer had asked some questions, written some notes, and departed without taking action. As for the accused himself, our informants agreed that he was a trusted and responsible employee who had worked for the theater for three years; he had never been in trouble with the law or the subject of any customer complaint during that period.

Our complainant was now engaged in a loud argument with the man in the booth, who did his best with his limited facility in English to fend off her accusations. Regina separated them and the officers retreated a few paces and conferred again. They were still puzzled. The complainant was obviously as sure and persistent as before, and the accused person was within the officers' reach. Yet, none of the usual reasons for "closing" a case were present.

The standard form (known as a "pink five") and standard protocol allowed the investigating officer following up a felony complaint to "close" it-a designation signifying no positive result and no purpose in further investigation-if 1) the investigation turned up facts clearly contradicting material facts 
given in the original complaint; 2) if the case hinged on a visual identification by the victim of the suspect, and the victim had been unable to recognize the supposed perpetrator by photograph or in the flesh; or 3) for some reason the complainant had turned hostile or uncooperative and refused to participate further in the case ("press charges" is something of a misnomer, but it captures the idea). Other than closing, Regina had only two options: he could continue to investigate or "clear" the case by arrest.

For those who watch the numbers as an index of police performance, "clearance" is an important statistic. Unfortunately, clearance is a rather slippery category and, as a result, the skeptical statistician would drape the touted "clearance rate" figures with garlands of caveats. Even arrest, the most solid of the clearance devices, often deserves a closer look. However, in the simple case like ours-one complainant, one incident, one perpetrator-the case is simply cleared by the arrest. To the extent that the performance of the unit will be assessed by the record watchers at headquarters, such a resolution bespeaks good police work.

No one doubts that the apprehension of the person identified with assurance by the victim of a serious crime is the fundamental object of effective police performance. The experienced cops in our trio well knew that basic truth of the job. In addition, both Regina and Trepcyk were reluctant to allow any contrary "sense of justice" to rule the situation. Both shook their heads and told me that they had no choice: arrest was the only appropriate response. When I asked about the probable response of their commanding officer, Sgt. Marty Browne, both agreed he would advise, "Take him." And yet ... .

And yet, Regina could not quite bring himself to pull the accused man from the booth and throw him into "the System." At the very least, he would probably spend the night in detention, an unpleasant experience for the novice. Quite possibly, he would have to pay a lawyer's fee. And even then, who knows how long and at what emotional cost he would have to wait for the System to discover its error. And Regina was coming to the clear conclusion that the complainant's accusation was false. "At times like this," Trepcyk told me, "this job stinks."

So we stood debating in a small group on the street, a few paces removed from the front of the theater where our complainant stood, now sullen, looking at the ground. We waited for Regina to make his move. He kept saying he was going to collar the suspect, but he stalled. I found it interesting that he never turned to his companions to ask for advice, and no one offered it gratuitously. He never indicated that he wanted Sgt. Browne to make or even to confirm the decision. All assumed that the decision was Regina's alone. Then, on the very brink of action, Regina backed off. He decided to keep the case open a while longer. "I don't have to take him this minute," he said. "I know where to find him." "He's not going anywhere," Trepcyk now offered in support. Regina decided to check with Muldoon, before proceeding further. 
Generally, Sgt. Browne had been urging the men in RIP to close their cases. To him, a growing log of inert open cases does not bespeak an active unit. An uncleared case, he thought, should remain open only so long as the continuing investigation promised new discoveries. The undying hope that something helpful just might turn up to move the case toward clearance by arrest did not justify the designation "active." A closed case could always be reopened; closing the case on paper did not have to close the mind of the assigned officer to new and fresh scents along the trail. In this instance, Regina articulated the basis for further investigation; his choice to keep the case open for further investigation. "I know Muldoon," he said. "He's one good cop. Let's see what he has to say."

Later that day at the stationhouse, I met Muldoon. He reported that the woman in the ticket booth had told him that the ticket taker had not left his post during the entire time that the complainant had been in the theater. She said she would have known if he had, because she was required to cover the door when he left for any reason. Muldoon also told Regina that the complainant had looked a little "strange" to him when he talked to her at the theater.

A few days after this meeting with Muldoon, I learned the conclusion of the matter. Regina had decided to "close" it. He told me that the accused man had agreed to take a lie detector test, and that the complainant had "lost interest." I talked to Marty Browne about the decision. Contrary to the prediction of his men, the sergeant had not favored the arrest. With a disparaging wave, he said the woman was obviously incredible and the man she accused was an honest working man. I asked what category of closing it would be on the "pink five." Twenty years of experience with departmental statistics produced an indulgent chuckle at my question, and he obligingly selected the "inaccurate facts" designation, though it was plain he hardly thought the choice worth making.

\section{IV}

\section{Another Case}

Before attempting any generalizations, perhaps another case might be useful. Tommy Longobardi-young, trim, athletic, commonsensical-had this one. As he waited one afternoon for the arrival of his suspect, Tommy filled me in on the case. The victim was an attractive young man named Robert $^{3}$ who, dressed as a woman, used the name Roberta and worked as a beautician on Delancy Street. "Not bad, either," Tommy confided with an appreciative smile. "He could have fooled me." (I might note that a creature of this sort of sexual ambiguity is not an avis rara in the East Village. I had observed another case involving what the cops call a "he/she" whose disguise was so convincing he/she worked the street as a full-time prostitute-and sometime accomplice in robbery.) Robert/Roberta (hereinafter designated as

3. Suspects and citizens, but not cops, have acquired false names herein. 
Robert) had served as a confidential informant for a narcotics detective in Brooklyn. He had first gone to that officer with the story of a robbery the previous day in Tomkins Square Park. When the detective asked whether he had reported the incident to the Ninth Precinct, Robert replied that he had not because he did not expect the police to believe him. The detective then accompanied Robert to the 9 RIP office where he offered his assurances to Longobardi and Sgt. Browne that Robert had always proved reliable as an informant, and that the detective believed his story of the robbery.

Robert then told the RIP officers that he had been sitting on a bench in Tomkins Square Park with a large portable stereo sound box when he was attacked by a man brandishing a knife. His attacker took the sound box from him, removed some $\$ 250$ in cash from Robert's pocket, and threw him to the ground. Robert had never seen the robber before but he was able to retrieve a plastic-coated ID card which the robber dropped as he fled. From this card, Longobardi had learned the identity and address of the suspect, a man named Mendoza. Longobardi went out and left a message for Mendoza at his home; shortly afterward, Mendoza phoned. Longobardi told Mendoza that a complaint had been made against him, and asked him if he would come into the RIP office and give the police his side of the story.

I should insert here that this move, which seemed strange to me, was not at all uncommon in the police work I observed. Longobardi, having what appeared to me ample probable cause to go out and arrest Mendoza, preferred initially to solicit "voluntary cooperation" from the suspect. In part, he thought that the case might be improved if he elicited a statement, and that the likelihood of obtaining one was greater in the relaxed conversation of an "informal" meeting than after arrest and Miranda warnings. In addition, Longobardi must have felt some uncertainty about the veracity of the complainant.

When I later asked Longobardi why he had not immediately gone out and made the arrest, he told me that he had been suspicious of the complainant's story from the start. Robbers do not often drop their identification papers as they retreat. Besides, there was something about the character of the complainant that suggested the possibility of other motives, despite the endorsement of the Brooklyn cop. At least, Longobardi felt, he would like to get a look at Mendoza and hear his side of the story. Longobardi could not say, however, whether he would have made an immediate arrest had he found Mendoza at home when he first went out looking for him.

Mendoza readily agreed to come in, and he arrived with his wife punctually at the appointed hour. He told Longobardi that he had never been arrested, and that he was employed by a messenger service. He said he had known the complainant for some while (though he thought Robert was Roberta), and had been in his apartment several times. On one occasion, as Mendoza was leaving, he had remembered that he had to bring home Pampers for his baby and he had no money. On his way out, when he spied the sound box on the table and noticed that Robert was not in the room, Mendoza impulsively 
decided to take the box. He had given it to a friend "to hold" in exchange for some cash. The following day, Mendoza said, he had seen Robert in the park. Robert had accused him of taking the sound box and demanded its return. Mendoza had at once acknowledged taking it and promised that he would get it back from the person to whom he had given it. Robert had asked for some security for this promise and Mendoza left him his laminated identification card as a token of good faith.

Longobardi asked Mendoza whether he could describe Robert's apartment and Mendoza did so. At my suggestion, Longobardi had Mendoza sit down and draw what he could remember of the layout and furnishings. He produced a crude but fairly detailed floorplan with window and floor coverings described and rugs, tables, and sofas drawn in. Longobardi thought about making the arrest, but decided to check further. He went to Robert's apartment, sketch in hand, and discovered that Mendoza was so accurate that he must have been in the place. He confronted Robert with this fact, and Robert simply stuck to his story: he had never before seen Mendoza, Mendoza had never been to his apartment to his knowledge, and he had no explanation for the obvious accuracy of the rendition.

Longobardi had asked Mendoza to come to the RIP office again. Longobardi told me that in the course of the matter, he had had Mendoza in a number of times. Mendoza had always appeared willingly and dependably, always accompanied by his wife. This regular and faithful attendance helped impress Longobardi with his veracity. Yet, I knew Longobardi was uncertain and hesitating. In fact, he later told me that on several occasions he had resolved to make the arrest but backed off and postponed action each time he saw Mendoza.

I had recently overheard some detectives saying that a departmental advisory had come out saying that the police polygraph lab was being insufficiently used and that detectives should have recourse to the facility in appropriate cases. I suggested to Longobardi that the Robert/Roberta case might be a good one for the lie detector. ${ }^{4}$ He liked the idea at once, in part because he had never seen the device in use and thought he might learn something about its operation. He telephoned the polygraph lab but was dismayed to learn that he would have to wait some two weeks for an appointment. In the meantime, Robert informed Longobardi that Mendoza had walked past the beauty parlor where he worked and had looked up at him in a "threatening" manner. To Longobardi the supposed threat was somewhat ambiguous, but the incident was another demonstration that the two were acquainted. "How else would Mendoza have known where Robert worked?" Longobardi asked me rhetorically.

At this point, neither Longobardi nor anyone else in the RIP office

4. The reader should not surmise from the fact that both of the cases I report here involve the polygraph in some way, that this device figured as a regular feature in the investigative routine of this unit. In fact, these were the only two instances I observed in which use of the "lie detector" was even contemplated. 
believed Robert. Still, Longobardi looked for a way to dispose of the case. I thought the fact that the diagram had checked out was a rather convincing corroboration of Mendoza's version. But Longobardi still wanted to go through with the polygraph test. I was not sure which of the two men was scheduled to take it. I would have thought it was Robert whose credibility was the primary issue. Besides, he was our witness. But Longobardi had scheduled Mendoza for the test; Mendoza seemed more than willing to vindicate himself. I got the report later. The test itself had apparently been inconclusive; however, the operator had the "feeling" that Mendoza was lying, so, according to Longobardi's admiring account, he came in and simply accused Mendoza of lying. Without further pretense, Mendoza confessed the whole incident precisely as Robert had given it, except that he would not admit to having used a knife. Shaking his head in disbelief, Longobardi made the arrest. We still do not know how Mendoza knew the layout of Robert's apart-

ment. We suspect that Robert is lying about their prior relationship, but in the light of the confession, the police concern with the complainant's peripheral credibility fades.

\section{V \\ Department Policy, Low and High Level}

Sergeant Marty Browne, 9 RIP's "Boss," is a tall, handsome man with a perpetually relaxed, easy-going manner and a revolver prominently strapped to his belt. He has about twenty years on the job, but he has no plans to take his generous pension and retire into another career, as so many cops do when they get the full twenty behind them. The simple fact is that he can think of nothing he would rather do than what he does. Although he has been in a command position for some years, he retains the street cop's distaste for the unending paperwork that occupies many hours of his day. He also feels that, because of the built-in garbage factor in the numbers, this paperwork does not provide the revealing statistics of police performance that many assume it does. Mainly, he cares about the people out there, the victims and potential victims of violence and loss. Through his customary chuckle of amusement at the daily traffic glints a genuine repugnance for the cruelty of criminals.

Browne and I have talked many times about the correct response of a line officer confronted with a story he does not believe is true or a victim or witness he knows will be regarded as incredible by the prosecutor or the court. Yet, I am left with the academic's uneasiness at a position not fully articulated. Browne is not a person to make rules out of cases. He has not attempted to put together an injunction from the varied experiences of his career. However, his general inclination toward making the collar seems to stem from two operative principles.

On one side, he has repeatedly argued that cops should respond to a robbery complaint from a "skel" in the men's shelter exactly as they would to a similar event in the posh 19th Precinct. A person who gets stabbed in a robbery, he says, is entitled to a vigorous reaction from law enforcement 
regardless of the fact that he was on his way to buy drugs with the money at the time he was hit. While he can understand the reaction of young prosecutors who are afraid they would be unable to persuade a jury to convict on the word of a flawed victim, Browne deeply believes it is wrong-and cowardlyfor a law enforcement officer, whether policeman or District Attorney, to shy away from the effort. The cop, in reaching the decision to arrest, should not take account of the character of the victim, even though it might put in question whether the victim will actually show up in court to pursue his complaint. Thus, while Browne may confidently predict that the victim offering the innocent story of his nocturnal business in drug territory at the time he was robbed was really an addict out shopping, Browne does not advise declining an arrest on that account. Besides, the next time that robber strikes, the victim may not be someone who has "assumed the risk."

The other ingredient of his reaction to these situations can only be recognized as the product of "institutional mentality." I refer to that pervasive philosophy, developed wherever people work in a hierarchy: "Cover thine own fundament." A cop who exercises individual judgment in favor of what he deems the just result-or even the administratively efficient result-in derogation of his book duty to make arrests risks admonishment if subsequent events prove his choice unwise. On the other hand, to arrest a positively identified perpetrator on the certain complaint of a citizen cannot be criticized later by superiors even though the complaint proves false or the court dismisses the case for failure of the complainant to press the charge. What Browne worries about when he calls upon this sacred precept is the minor weak case, rejected by the cop, that later turns into a tragedy that might have been averted. "Where does that leave the cop," he asks, "who let the perpetrator slip through his hands the first time he had a hold on him?" The timid judge who worries about setting low bail on the minor case lest the released defendant commit a more serious crime while out on bail fears only the slings of unjust public censure. The cop fears the arrows of adverse career impact.

We had a case that neatly confirmed Sgt. Browne's thesis. The case came in as little more than a push and shove between a couple who were cohabiting after meeting at a drug rehab center (what the RIP cops called a "Methodonian marriage"). The woman recited a list of grievances, including an attempt by her partner to "trash" her apartment and an encounter in which she claimed he had seized her purse by force. For his part, the man hotly denied the accusation and told the police of several other minor events concerning their partnership, which the woman denied. When further investigation and challenge proved him correct about these peripheral details, and when the police learned that the woman had three outstanding warrants against her (though she had asserted that she had never had any trouble with the law), the investigating officer, after agonizing over the question for a considerable period, released the man and held the "victim" on the warrants. A week or so later, we learned that the building in which the couple had lived had been "torched," that the man was a serious suspect in the arson, and that 
he had disappeared from his usual haunts. Fortunately, no one had been hurt in the fire, but Sgt. Browne could not resist thinking aloud, "What if . . . ?"

In fact, the Department has a policy against non-arrest in a "domestic" dispute. Partly the rule is based on the likelihood of later flare-up and injury in cases of that sort. Of the various options for settling domestic disputes, one famous study reported that arrest is most highly correlated with subsequent peace. ${ }^{5}$ Partly the policy responds to the criticism that male cops have not taken the complaints of beaten or threatened women seriously enough. The policy therefore might not be applicable in a case where no aggression was apparent and the woman's complaint seemed plainly false.

I took the question of police discretion to decline arrest on the incredible complaint to the Deputy Police Commissioner in Charge of Legal Matters, Kenneth Conboy. Conboy is a thoughtful and scholarly person who has shared top-level responsibility in the New York Department during the long and highly respected tenure of Commissioner McGuire. A former prosecutor, Conboy has never held any other position in the Police Department but has become completely conversant with its operations from the street level up.

In discussing the responsibilities of the investigative officer (as distinguished from the cop on patrol duty), Conboy repeatedly stressed the duty to arrest on the credible complaint. I stopped him on the word "credible." Was he suggesting that the Department favored the line officer making the credibility call? Did the Department provide any training or guidelines for the exercise of such judgment? Were the brass concerned that encouragement of discretion in these matters might be an invitation to corruption, or the semblance of it? He replied that the investigating officer should be sure that he could articulate an objective basis for his decision and that the decision should be reviewed by a superior officer, perhaps with the advice of the Department's legal bureau. As for the appearance of impropriety, if the judgment was wellbased and soundly made, such attacks could be deflected. Basically, the Commissioner expressed his confidence in the common sense of the street officer familiar with his clients and concerned with justice.

\section{VI}

\section{Thoughts and Tentative Conclusions}

From the cases recited above and about a half dozen other experiences like them, I assembled some limited generalizations and ventured some opinions of my own:

1. Police officers on the investigative level generally believe that they are required to clear a case by arrest when they have: a) an unshakable and

5. D. Bayley, Police and Community Attitudes in Battle Creek, Michigan: An Interim Report on the Evaluation of the Police Improvement Project (September, 1981) (unpublished report by the Police Foundation). 
insistent complainant stating facts amounting to a felony; b) a story uncontradicted by objective evidence; and c) a positively identified perpetrator within reach.

2. In spite of this belief, a good and conscientious officer will hesitate to arrest if he harbors strong personal suspicions regarding the complainant's veracity.

3. While the officer assigned to the case may occasionally share his misgivings with his teammates or turn to a superior officer or outside advisor, he generally (but erroneously) believes that the decision is his alone.

4. Although arrest is a commonplace event in their work, even officers of many years' experience view an arrest as a significant exercise of power, with serious consequences to the person arrested (particularly the relatively "clean perp"), regardless of the eventual outcome of the case in court.

5. Line officers accord surprisingly little consideration to the possible adverse impact on their careers from either overstepping their proper function or from making the decision on credibility grounds when they are personally convinced that the complainant has lied to them about some particular in the case.

6. Credibility decisions are relatively unaffected by considerations of character or status of the complainant alone. Independent of the question of veracity, however, there is a certain wariness about instituting a case that depends upon the testimony of a person deemed highly unlikely to pursue it further in the cold light of the day after.

7. A local commanding officer, however sensitive, is likely to be less responsive to the credibility question than the officer involved in the case.

8. The high command generally approves the exercise of informed discretion in the credibility call to a far greater extent than the line officer suspects. 9. Virtually no training or advice is available to the investigating officer to assist his native common sense in appraising veracity.

Reflecting on these fragmentary observations of cops working in the field, I am hesitant to reach any curbstone resolutions of fundamental claims of duty and humanity. Indeed, in framing the preceding list, I am painfully conscious of how scant the underlying data are. Nevertheless, with all appropriate disclaimers and caveats, I shall append some of my conclusions.

My governing conclusion is that the cop's informed instinct toward a just choice should be encouraged by official recognition. Most people often behave as they are expected to, and cops who are expected to take the job and the consequences of their actions as matters of conscience will perform more conscientiously. Cops should think of themselves as functioning members of a system that, inter alia, seeks to separate truth from falsehood. Less of the menial mentality-that you do not get in trouble by sticking to the narrowest definition of your own jurisdiction-would be welcome. We could use more of the attitude that the judgment risk must be shared all up and down the line. Humanity and intelligence should not be bootlegged into the system. Rather, police officers should be instructed that they are entitled, and expected, to formulate decisions based upon informed judgments and ordinary 
considerations of hardship, rather than being led to believe that such considerations are illicit in a system of mechanically applied rules and regulations. Police officers are probably positioned at least as well as judges and prosecutors to recognize the false story, and much better to chase it down. The ends of justice are not better served by promoting the fiction that the intake funnel downtown-casual and clogged-is the appropriate forum for weeding out the wrong cases. Better would be a policy that fosters responsibility where it can be well exercised and encourages the development of the skills to enhance judgment and embolden action.

Communication. It will come as more of a surprise to the line officers than to the commanders to learn that the Department favors the use of common sense in the performance of duty. There are a few obvious ways the Department could communicate such a policy. First, of course, would be simply to tell the troops, through the many training programs and publications provided for investigative officers, that the Department does not consider the automatic arrest on probable cause to be the inescapable call of duty, but expects its investigative officers to exercise sound judgment in the assessment of credibility and to take that factor into consideration in deciding whether an arrest is the correct move. In short, the Department could define probable cause to include the veracity factor.

When the vast organization that is the New York Police Department really means what it says, it issues guidelines and procedures. While such bulletins are invariably taken too literally, if not actually misunderstood, they serve useful purposes nonetheless. The few guidelines I propose here largely represent codifications of the elements of sound judgment as distilled from the reactions of Sgt. Browne.

Consultation. Rules should provide that a complaint providing probable cause to arrest may be closed without arrest only on the approval of a supervising officer or the concurrence of two peers. Normally, cops will seek their boss's approval, as they should. But much the same purpose may be served by directing line officers to consult with one another and find a couple of fellow officers who not only support the decision but are willing to be so recorded. The virtues of such a command/consultation rule are three: First, like all back-up systems, the rule provides some check on the appraisal of the officer closest to the scene. Some idiosyncratic distortion may occur even in the sensibilities of the street-wise cop; the much-praised nose, on which many cops rely, can lead a cop astray. (I have witnessed such olfactory betrayals on more than one occasion; remarkably, confidence remains undented.) Second, the professional pride-or whatever it is that generally appears to inhibit solicited sharing of responsibility-might recede before the official edict. Third, the career-cautious cop would have considerable protection to encourage him to do what he knows is right.

Grounds. Here, it is particularly important to limit the guidelines to a few basic tenets, else the discretion we seek to enhance will be shrunk to conform to a new set of rules, examples will be elevated to mandates, and the design 
will be lost. The general principle appears to be this: A police officer may decline an arrest when in his judgment the complainant has not truthfully stated some fact essential to the establishment of probable cause. The officer's judgment on veracity should be based upon some articulable perception or fact credibly contradicting the complainant's account of the incident. Arrest should not be declined because the police officer believes that the complainant has misinformed him of some fact surrounding the incident that is inessential to probable cause. (This is the typical case where the victim correctly describes the robbery and accurately identifies the perpetrator but gives the police a false story of why he happened to be in that neighborhood in the first place. The "Methodonian" case might also fit in this category.) Nor should the police decline the arrest because they believe that the character or background of the complainant renders the person generally unworthy of belief.

This latter factor may prove to be one of the more sticky. Particularly where the victim appears to be of a "lower" social position than the alleged perpetrator, it is difficult to resist the inference of false accusation. Yet prostitutes do get robbed by respectable-looking young men from the provinces. In such cases, the instinct of the officers I observed was correct: investigate further. While initially skeptical, they commonly call upon that most valuable maxim of the good investigator: "I've seen stranger things." If the accused person has a fixed abode, a job, family, and so forth, cops feel relatively confident of finding him again if further investigation corroborates the story they hesitated to accept at first. From what I have seen, they will investigate the story of the drunk, the whore, the addict, even the criminal, who claims to have become a victim. They know that often the very people who are not the prosecutor's first draft choice as witnesses become the predators' preferred targets. Therefore, the cop's discretion should not be affected by a prediction, however well-grounded, that the case will be thrown out either for failure of the complainant to appear or the cautious lawyer's reluctance to rest a serious felony prosecution on the slender credibility of such a person.

One good reason for advising police to ignore their hunches concerning disposition of cases is that they are often wrong. More than once, police have told me with surprise and approval that prosecutors had indicted and obtained good pleas in the men's shelter cases. Systematic cynicism and the regrettable tendency of each component of our criminal justice system to overstate the flaws of the others render suspect police predictions of judicial or prosecutorial disinclination.

Beyond that, it surely will not do to allow police to establish a class discrepancy in the responsiveness of the police to claims of crime. However often I have heard police in the Ninth Precinct bemoan the paucity of honest and upstanding victims, I have yet to hear a word indicating reluctance to pursue the cases brought to them by the parade of flawed people they deal with. We should keep it that way. Insofar as credibility is in truth a product of character, that judgment should be left to the courts and their counselors. 
It bears emphasis that I am not proposing any radical change in the role of police judgment in the arrest decision. In fact, as George Fletcher suggests elsewhere in this volume, ${ }^{6}$ the term "discretion" may be something of a misnomer in this context. "Probable cause"-that marvelous amorphous, allpurpose validator of the official move against individual sovereignty-incorporates among its several ingredient factors the cop's experienced assessment of the likely significance of the events he perceives. Time and again, courts have reminded the skeptical police that their readings of the things they see and hear are entitled to judicial deference when the lawfulness of a detention or arrest is under review. Therefore, there is surely room in the definition of probable cause for the credibility factor. The account of a witness, however vociferous, supplies probable cause only if the decisionmaker either finds it believable or at least has no good reason to reject it as incredible. The judgment necessary to arrive at a conclusion regarding credence is a rather different operation than that normally referred to as discretionary. Upon one or the contrary conclusion on credence, the decisionmaker has no choice remaining. To say (as this article has rather too loosely) that the cop has "discretion" whether or not to believe the victim does not accurately express the process of weighing credibility. Veracity is a fact, more or less accurately judged by the responsible public officer. To say that the officer should actively and earnestly attend to the judgment he is required to make is not to say that he should be entrusted with discretion in determining the appropriate course of action upon a complaint.

Yet so it appears to the cop on the line. Police officers are not accustomed to thinking of themselves as factfinders. While they act upon hunch, suspicion, and belief all the time, they rarely regard themselves as coming to a considered and irrevocable judgment on a matter of uncertainty. To the extent that policy encourages the exercise of judgment in the inherent credibility call, it becomes necessary to inform the line officers that, in arriving at the probable cause conclusion, they are expected to consider factors specifically affecting veracity. Line officers need to be specially instructed that probable cause may be founded only upon credible accounts and have the appropriate ingredients of the perception of truth or lack of it spelled out. They correctly believe that, despite their skepticism, a presumption of veracity ordinarily supports the citizen's story. They are less well aware that certain specific and clearly articulable events, objects, or contrary accounts will overcome that ordinary acceptance of a citizen's account. Defining precisely what is sufficient to rebut the presumption is challenging (and I shall not attempt it here) but, I hope, doable. In any event, if the presumption is rebutted, credibility fails and probable cause disappears.

In the final analysis, there are cases (including some recounted here) in which no recital of factors affecting credibility can be mechanically applied to produce an objective conclusion regarding veracity. To call that conclusion a

6. Fletcher, Some Unwise Reflections About Discretion, LAw \& ConTemp. Probs., Autumn 1984, at 269. 
"found fact" satisfies the formalities of determining probable cause, but only crudely conforms to the actual process of decisionmaking. In many of the cases as they come down the chute, the choice seems much more readily described as discretionary. Without parsing the term as finely as does Fletcher, discretionary decisions are choices made in the exercise of official power without fear of reversal, except for the most clear deviation from a customary norm. To say that the cop has discretion whether to arrest on the story given is to tell him that he must rely upon some internal reaction system based on inchoate perceptions, unarticulated considerations of probability, and the unofficial components of private judgment. Simply put, discretion means to the cop, "You may be wrong, but you're right anyway." In a rulebound organization, that is not an easy lesson to get across.

\section{VII}

\section{IN Sum}

Scholars, contemplating our criminal justice system, most frequently find their attention drawn to some point where an individual makes a choice on the basis of his or her own precepts of what is right. It is at these discretion points that the itch is felt. Those seeking to enlarge the province of law unite with those harboring distrust of government power in searching for some due process with which to bridle the official exercising his or her discretion. Charge decisions, grants of immunity, plea bargains, sentences, parole release or revocation are some of the perennial favorites for recommendations of "guidelines," mechanisms for review, adversary hearings, and the like. Excellent though many of the members of that company may be, they err in their reliance on guidelines as the solution.

There is no escape from the reality that the quality of criminal justice reflects the quality of the people who run the system in all of its parts. The solace of standardized rules and procedures is largely illusory. Rigid rules tend to ossify individual responsibility and discourage individualistic thinking. Those who would shrink discretion obey the precept: "Treat likes alike." However, the overriding lesson of experience in our criminal justice operation is that every case is different. The major worry is that the people out there dealing with the problems will lose their appreciation of the differences between the cases and will begin reacting to them as repetitive. There is nothing quite like a good set of rules cum guidelines to bring common elements to the fore and obscure differences. If nothing else, our experience with mandatory minimums in drug sentencing should have taught the sterility of the reduced factor method of response. The learned fact should be that crimes and criminals emerge from a rich variety of circumstances. Separately and in combination, the variants can never be fully anticipated or assessed; yet they are often critical to forming the just response.

So, to the widest extent practicable, I favor discretion. Of course, it is helpful for those charged with responsibility to know what others are doing in the same fix, so there should be conferences, publication of results, studies 
and comparisons, and candor in the exchange of ingredient factors. Prosecutors should not view inquiries into decisionmaking policies and practices with hostility or even suspicion, and judges should welcome analyses of their product. However, such study, from within as well as without the system, should be made clearly in aid of firmly lodged discretion rather than used for the erosion of responsibility. For police, no less than for any other decisionmakers, the ingredients of sound decisions are confidence and data. Knowing one is expected to think about one's choices is the indispensable first step in the development of decisional skills. Then, information concerning what others think to be significant components of a good choice becomes a useful working guidance system. Peer consultation is an excellent means to encourage articulation, particularly among a group not accustomed to supplying reasons for their actions.

We need not be upset by acknowledged discretion in the hands of our police. Surely there are dishonest and corrupt cops who might view the recognition of police judgment-making as an invitation to a fruitful venture in discretion peddling. Just as surely, one cannot design a criminal justice system around the fear of uncontrollable subversion.

Additionally, the system itself stands to gain from the development of police responsibility in the assessment of witness credibility. The necessary job of judging veracity does not get any easier as the case progesses toward disposition, and the judgment makers do not become any more adept. Quite possibly, therefore, discretion encouraged at the police level will not only relieve the burdened system of unwanted cases and improve the approach of the cop to the job, but will also result in better-that is, more accurate-dispositions. Without disparaging the importance of the oath, the solemnity of higher forums, or the effectiveness of adversary challenge, there are surely cases in which the cop, schooled on the streets of the neighborhood, coming immediately on the fresh case, possessing various investigatory resources and time to use them, can make a better appraisal of the likely truth than any other component of the process. 
